\title{
Forest Fires in India: A Review
}

\author{
Reuben Sewak $^{1}$, Mehak Vashisth ${ }^{1}$, Lovleen Gupta ${ }^{1 *}$ \\ * Corresponding Author E-mail: lgupta@dce.ac.in \\ ${ }^{1}$ Department of Environmental Engineering, Delhi Technological University, Delhi - 110042, \\ India
}

\begin{abstract}
Forest fire has become extreme and has increased in frequency worldwide with India being no exception. In view of this, the present-day knowledge about the forest fire condition in India has been reviewed. The forest cover in India is divided into four clusters namely North Himalayan, North-Eastern, Southern, and Central. Of these clusters, it has been found that though the NorthEastern cluster encompasses the maximum area (55\%) of all the clusters in India, it accounts for meagre $16 \%$ of the burnt forest area. The central cluster has been found to be the most vulnerable to forest fires as $\sim 56 \%$ of the total burnt area lies in this region, though it covers only $28 \%$ of the forest cover. In North-East fires tend to concentrate in a smaller area that is subject to repeated burns whereas in Central and Southern India they are more expansive. The impacts of forest fires on biodiversity, forest species, climate change, and soil characteristics in India are presented and various strategies adopted by the Indian government in order to detect and control the forest fires are presented. Additionally, the economic impact of forest fires is estimated to be over INR 1101 crore/year.
\end{abstract}

Keywords: Forest Fire, Clusters, MODIS, Forest Survey of India, Flora, Fauna

\section{Introduction}

Forests are crucial to life; they sustain biodiversity and provide endless incalculable products and important ecosystem resources such as storage of carbon, flood \& landslide control, clean supply of water, medicines, and crops (Bonell et al., 2010; Krishnaswamy et al., 2009). The global forest comprises 4.06 billion hectares of the area which is equivalent to $31 \%$ of the total land area (FAO, 2020). Approximately 1.6 billion people across the world depend on these forests, including 300 million people living within them (WWF, 2011). Between the years 2000 to 2010, a decline of the forest area by about 5.2 million hectares per year ( $0.1 \%$ of the total forest area) has been discerned (FAO, 2020). Forests face various aggravations that can cause harmful effects to their health and productivity along with decreasing their ability to supply products and services. Forest fires being one of them, is ubiquitous and can take place in nearly any ecosystem (Archibald et al., 2013). While fire has been used in crop rotation, agricultural plowing, and 
the production of pasture for domesticated animals since ancient times, socioeconomic changes have caused traditional uses to be abandoned (VidalMacua et al., 2018).

Forest fires are accounted to be a burgeoning phenomenon over the years ravaging ecosystems, communities, and economies (Jhariya \& Raj, 2014). Increasing human reliance on forests for a number of reasons leads to their fragmentation which further aggravates fire events (Cochrane, 2003). Various studies (Cochrane, 2003; Grutzen \& Andreae, 1990; Penner et al., 1992) mention that forest fires have become extreme and have increased in frequency worldwide. The impact of forest fires have been documented on biodiversity (Granström, 2001), human life (Finlay et al., 2012; Fowler, 2003), climate change (Wotton et al., 2003, 2010) along with their associated economic impacts (González-Cabán, 2013; Kim et al., 2011; Úbeda \& Sarricolea, 2016). India with 21.67\% (7,12,249 $\mathrm{km}^{2}$ ) area under forests is no exception to forest fires. 55\% of forests in India are vulnerable to intermittent fires (Forest Survey of India, 2011a) and fires affect around 3.73 million hectares of forests annually (Chandra \& Kumar Bhardwaj, 2015). In addition, population growth in India has triggered substantial deforestation, causing further fragmentation of existing forests. "Present biotic pressures like logging, grazing, and collection of non-timber forest products have also rendered Indian forests susceptible to fires" (Narendran et al., 2001).

This study reviews the scientific literature available to date that examines the forest fires in India from an environmental, social, and planning perspective. This study presents the overall forest and forest fire scenario in India, including the impacts and fire prevention strategies. This paper presents a new contribution to the knowledge of forest fire scenario in India.

\section{Forest fire in India: general trends}

India occupies just only $2.5 \%$ of the global geographical area, $1.8 \%$ of the overall forest area and it supports $16 \%$ of the total human population (Ashutosh \& Satendra, 2014). The forest cover in India, according to the Forest Survey of India is $71.22 \mathrm{Mha}$, constituting $21.67 \%$ of the total area, which represents $3.02 \%$ very dense, 9.39\% moderately dense and $9.26 \%$ as open forest ( Forest Survey of India, 2011b). Out of the 647 districts in India, nearly 380-445 districts encountered fires every year from 2003 to 2016 (World Bank, 2018). According to MODIS (Moderate Resolution Imaging Spectroradiometer) forest fire detections, approximately 37,059 fires were detected in 2018 (Forest Survey of India, 2011b). The classification of Indian forests is shown in Table 1, which shows that nearly $4 \%$ of the forest area in the country is extremely vulnerable to fire, while more than $6 \%$ is found to be highly vulnerable to fire.

Table 1: Classification of Indian Forests

\begin{tabular}{|c|c|c|}
\hline Forest fire prone classes & Forest cover $\left(\mathbf{i n} \mathbf{k m}^{\mathbf{2}}\right)$ & $\begin{array}{c}\text { \% of total forest } \\
\text { cover }\end{array}$ \\
\hline Extremely fire prone & 25,617 & 3.89 \\
\hline Highly fire prone & 39,500 & 6.01 \\
\hline Fire prone & 75,952 & 11.5 \\
\hline Moderately fire prone & 96,422 & 14.7 \\
\hline Less fire prone & $4,20,625$ & 63.9 \\
\hline Total & $\mathbf{6 , 5 8 , 1 1 6}$ & $\mathbf{1 0 0}$ \\
\hline
\end{tabular}

Source (World Bank, 2018)

With respect to the forest area and the fire ecology variation therein, India can be divided into four geographical clusters viz. North Himalayan, North-Eastern, 
Southern, and Central as shown in Figure 1. These clusters encompass 90\% of the total forest cover in India and encountered $98 \%$ of the total fire points detected in India from the year 2003-16. Although fires are spread across the identified clusters, they happen more frequently in certain areas and affect the forest more than in others. The North-Eastern cluster accounts for the maximum forest cover of $36 \%$ and the number of fire detections (40\%), however, the maximum forest burnt area (56\%) is in the Central cluster (Figure 2), which suggests that the Central cluster is the most vulnerable region in India.

The Central cluster encompasses states like Madhya Pradesh and some districts of Chhattisgarh and Rajasthan. With a subtropical climate, this cluster encounters average rainfall from $800 \mathrm{~mm}$ to $1,800 \mathrm{~mm}$ with the mean annual temperature varying between $22^{\circ} \mathrm{C}$ to $25^{\circ} \mathrm{C}$. It mainly consists of forest species such as Tectona grandis, Shorea robusta, Lagerstroemia parviflora, and fires therein are caused by slashing and burning agricultural practices that help to collect non-timber forest products (Saha, 2002).

Forest fires are common and widespread in this cluster's dry and humid deciduous forest areas in the borderlands of Chhattisgarh, Maharashtra, and Telangana. (World Bank, 2018). States including Arunachal Pradesh, Assam, Manipur, Meghalaya, Mizoram, Nagaland, and Tripura are primarily part of the North-Eastern cluster. It experiences rainfall of 2,100 mm to 3,500 mm. During the winter months (October-January), temperature varies from $11^{\circ} \mathrm{C}$ to $24^{\circ} \mathrm{C}$, while during the summer months (March-June) it encounters temperature ranging from $18{ }^{\circ} \mathrm{C}$ to $29^{\circ} \mathrm{C}$. Important species include Schima wallichii, Tectona grandis, Callicarpa species, and Pinus kasya, etc.

The maximum number of fires detected (55\%) were in the North-Eastern cluster which also accounts for the maximum forest cover of 36\% (Figure 2). In this cluster, fires tend to concentrate in a smaller area that is subject to repeated burns. "This repeated pattern of burning on small forest area is consistent with the practice of shifting cultivation (jhum) seen throughout the northeast. Fires in North-Eastern cluster, occur mainly from slash and burn agriculture”(World Bank, 2018). Due to population growth, there has been a reduction in time between fires, is has reduced from 20-30 years to 2-3 years (Puri et al., 2011), breaking the ecosystem's resilience.

Coniferous forests in the North Himalayan cluster region comprise species such as fir, spruce, and pine. Due to the harsh conditions, tree growth in this cluster is minimal. The annual rainfall ranges between $1200 \mathrm{~mm}$ to $1500 \mathrm{~mm}$ and the temperature varies from sub-zero to $35^{\circ} \mathrm{C}$. The North Himalayan cluster is spread over states such as Kashmir, Uttarakhand, and Himachal Pradesh. Important species include Shorea robusta, Pinus roxburghii, Quercus leucotrichophora, and Mallotus philippinensis. Fire is used as a tool by indigenous communities of the area to clear grass that contributes to forest regeneration (Bahuguna \& Upadhay, 2002).

Southern Cluster consists of states like Karnataka, Kerala, Tamil Nadu, Andhra Pradesh, Telangana, and some districts of Maharashtra. This cluster encounters average rainfall from $1000 \mathrm{~mm}$ to $1,800 \mathrm{~mm}$, while the mean annual temperature varies between $20^{\circ} \mathrm{C}$ to $26^{\circ} \mathrm{C}$. Important species include Dipterocarpus indicus and Vateria indica. Fires in Southern clusters are more expansive and occur due to human accidents, for management of forest, and due to slash and burn practices (Kodandapani et al., 2004). 


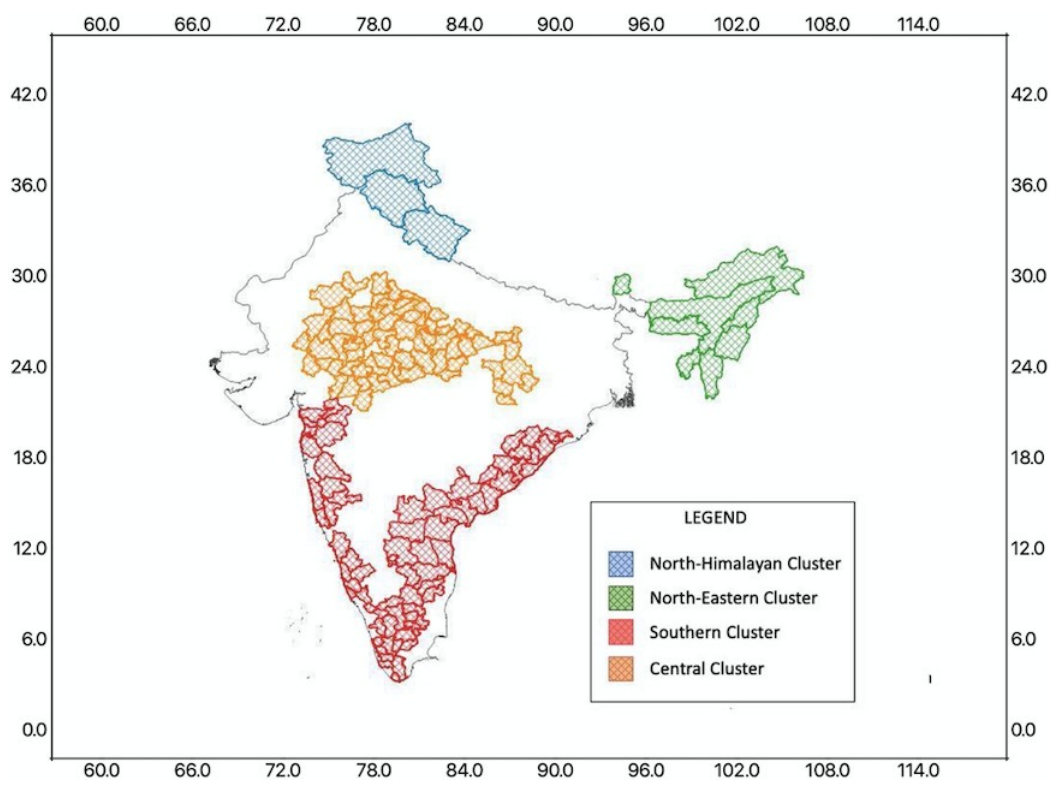

Figure 1: Map showing forest clusters found in India

Of the total forest fire detections in India from the year 2003-16, 20 districts accounted to $40 \%$ of all forest fire detections (World Bank, 2018), majority of them lie in the North Eastern cluster. Those 20 districts are listed in Table 2.

Table 2: Total number of fire detections in top 20 districts, 2003-2016

\begin{tabular}{|l|c|c|}
\hline \multicolumn{1}{|c|}{ District, State } & Cluster & $\begin{array}{c}\text { Share of fire } \\
\text { detections, 2003- } \\
\mathbf{2 0 1 6} \mathbf{( \% )}\end{array}$ \\
\hline Lunglei, Mizoram & North East & 3.82 \\
\hline Karbi Anglong, Assam & North East & 3.48 \\
\hline Dima Hasao, Assam & North East & 3.3 \\
\hline Churachandpur, Manipur & North East & 3.15 \\
\hline Mamit, Mizoram & North East & 2.56 \\
\hline Lawngtlai, Mizoram & North East & 2.42 \\
\hline Tamenglong, Manipur & North East & 2.32 \\
\hline Aizawl, Mizoram & North East & 1.91 \\
\hline Gadchiroli, Maharashtra & Central & 1.78 \\
\hline Dhalai, Tripura & North East & 1.77 \\
\hline Champhai, Mizoram & North East & 1.69 \\
\hline W. Khasi Hills, Meghalaya & North East & 1.48 \\
\hline Narayanpur, Chhattisgarh & Central & 1.45 \\
\hline Ribhoi, Meghalaya & North East & 1.37 \\
\hline Kandhamal, Odisha & Central & 1.35 \\
\hline E. Garo Hills, Meghalaya & North East & 1.33 \\
\hline Ukhrul, Manipur & North East & 1.32 \\
\hline Chandel, Manipur & North East & 1.32 \\
\hline Bijapur, Chhattisgarh & Central & 1.31 \\
\hline North Tripura, Tripura & North East & 1.16 \\
\hline Top 20 total & & $\mathbf{4 0 . 2 8}$ \\
\hline
\end{tabular}

Source (World Bank, 2018)

Conversely, with regard to the total area affected by forest fires, the top 20 districts which represented $48 \%$ of the total area affected by fire between 2003 and 2016, majority of them belong in the central cluster, (World Bank, 2018). These 20 districts in the central cluster are listed in Table 3 
Table 3: Total area affected by fire in top 20 districts, 2003-2016

\begin{tabular}{|c|c|c|}
\hline District, State & Cluster & $\begin{array}{c}\begin{array}{c}\text { Share of burnt } \\
\text { area, 2003-2016 } \\
(\%)\end{array} \\
\end{array}$ \\
\hline Gadchiroli, Maharashtra & Central & 8.24 \\
\hline Bijapur, Chhattisgarh & Central & 5.29 \\
\hline Khammam, Telangana & Southern & 3.86 \\
\hline Narayanpur, Chhattisgarh & Central & 2.7 \\
\hline Warangal, Telangana & Southern & 2.56 \\
\hline Koriya, Chhattisgarh & Central & 2.35 \\
\hline Adilabad, Telangana & Southern & 2 \\
\hline Chandrapur, Maharashtra & Central & 1.95 \\
\hline Surguja, Chhattisgarh & Central & 1.9 \\
\hline Kurnool, Andhra Pradesh & Southern & 1.8 \\
\hline Amravati, Maharashtra & Central & 1.78 \\
\hline Y.S.R., Andhra Pradesh & Southern & 1.71 \\
\hline Prakasam, Andhra Pradesh & Southern & 1.7 \\
\hline Dakshin Bastar, Chhattisgarh & Central & 1.61 \\
\hline Bilaspur, Chhattisgarh & Central & 1.6 \\
\hline Raipur, Chhattisgarh & Central & 1.56 \\
\hline Betul, Madhya Pradesh & Central & 1.46 \\
\hline Champhai, Mizoram & North East & 1.42 \\
\hline Lawngtlai, Mizoram & North East & 1.35 \\
\hline Dima Hasao, Assam & North East & 1.34 \\
\hline \multicolumn{2}{|c|}{ Top 20 total } & 48.18 \\
\hline
\end{tabular}

Source (World Bank, 2018)

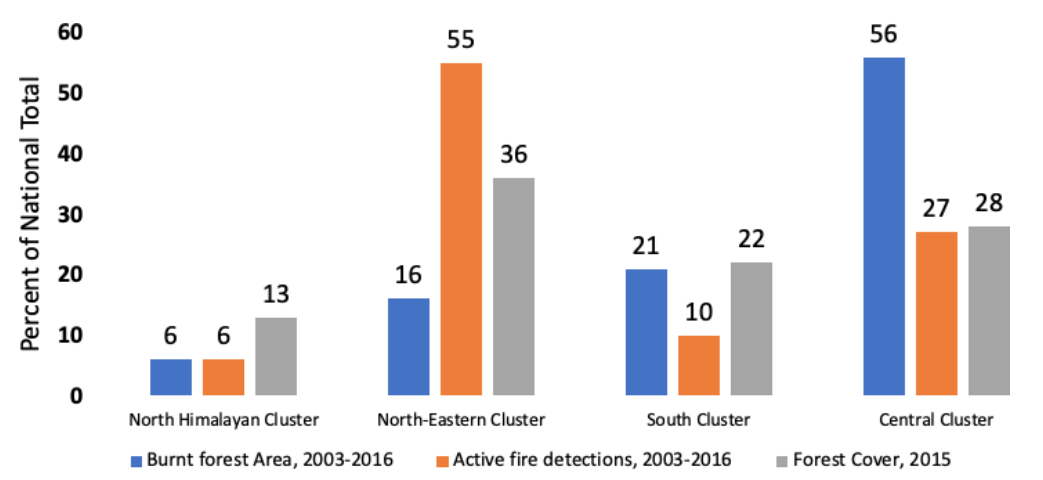

Figure 2: Burnt forest area, Active forest fire detections and Forest Cover from 20032016 ( World Bank, 2018)

\section{Impact of forest fires}

\section{Impact on biodiversity}

India is rich with rare and complex floral and faunal resources, accounting collectively for $60-70 \%$ of the world 's biodiversity (Creswell I, 2018; Producer et al., 2006). Wildfires can have devastating effects on biodiversity by destroying trees, ecosystems, and food supplies and by increasing the resulting susceptibility to predation of surviving animals (Green \& Sanecki, 2006; Kodandapani et al., 2008; Letnic \& Dickman, 2005; Pelegrin \& Bucher, 2010). 


\section{Flora}

Spatial factors such as the location of a plant's dormant bud, the sub-surface distribution of reproductive structures, and the depths below the surface from which new shoots emerge depict an individual plant's growth behavior post-fire (Flinn \& Pringle, 1983; Paula et al., 2009). Depending on the intensity and return period, fires can be beneficial or harmful (Verma \& Jayakumar, 2012). According to Cochrane et al., 2009, there has been a "drastic alteration" in the species structure and abundance found in the Nilgiri Biosphere Reserve in the southern cluster, with reduced seedling density observed in the forest area. In the Central cluster Jhariya, M.K. S.S. Bargali, 2014 find similar trends in the Bhoramdeo wildlife dry deciduous forests of Chhattisgarh. Kittur et al., 2014 observe that the regeneration and size structure of economicallysignificant species of plants such as Sal is disrupted by repetitive fires. In the North Himalayan cluster, fire has been a cause for damage to seedlings in Uttarakhand's pine, oak, and mixed deciduous forests (Parashar et al., 2003). Human pressures such as burning, lopping, grazing, and collection of leaf litters have slowly resulted in the transformation of Uttarakhand's oak forests into pine forests, as fires promote the growth of chir-dominated pine forests (Singh et al., 1984).

\section{Fauna}

In the North Himalayan cluster, the loss of flora and fauna triggered by wildfires during the summer in these forests is higher than any other human induced factor (Hussain et al., 2018). Evaluating the role of fire (Rodgers, 1986) finds that fires in some areas can be beneficial for wild herbivores. Regulated patchwork burning can improve habitat for grazing species such as swamp deer and chital for small areas of moist grassland. However, the advantages of fire decrease as habitats get drier and fire frequency increases. Also, while fire may be helpful to some degree in promoting habitat for some wild herbivores, not all species benefit. Nests, dens, and eggs can be destroyed by even low-intensity surface fires, killing young animals that cannot escape fast enough. (Rodgers, 1986).

\section{Impact on soil properties}

Forest fires have a significant impact on post-fire forest composition and structure of soil (Jain et al., 2008). It can affect many physical and chemical soil properties including "loss of organic soil and structure, reduced porosity, and increased $\mathrm{pH}$ " (Certini, 2005; Debano, 1991). Indirect consequences, include increased water repellence resulting in reduced penetration and increased runoff, which leads to increased erosion (DeBano, 2003). Fires of higher intensity can considerably deplete the soil and alienate it of nutrients and organic matter (Chandra \& Kumar Bhardwaj, 2015). In South Kashmir of the North Himalayan cluster (Khaki, B.A., Singh. V.R.R., Wani A.A. \& Thakur, 2015) discovered evidence that the overall soil carbon and nitrogen content in burnt areas were lower than unburnt areas, while "phosphorus and potassium" were higher in burnt areas. "The shortening of fire-associated jhum cycles in North-Eastern cluster has had a negative impact on soil fertility". Shortened jhum cycles lower the amount of fallow biomass available for combustion, and offer less time to recuperate soil fertility resulting in lower economic yields and output (Ramakrishnan, 2007).

\section{Impact on climate change}

Climate change has been observed to be on the rise due to the dominant anthropogenic activities that have been exceeding the bounds of natural 
variability. One of the numerous consequences associated with climate changeis forest fires (Stephens, 2005). Forest fire and climate change possess a feedback effect. Human-instigated climate change has attempted to put more prominent pressure on numerous forest species and has weakened their ability to withstand fires. Within certain regions of the world, more extreme and recurrent wildfires are expected to occur in the future due to climate change (Hemp, 2009; McKenzie et al., 2004; Pitman et al., 2007; Wilson et al., 2010). The appropriate period to find out the fire sensitivity (frequency and intensity) is during the summer when the moisture content and wind speed in the atmosphere is low (Murthy et al., 2019; North et al., 2015; Piñol et al., 1998). This can be regarded as one of the major reasons for how the drought-prone areas are easily drawn to wildfires. The effect of fluctuating climatic patterns on the forest fires of India has also been pointed out by Joseph et al., 2009. They were able to show the shift in the extent of grasslands and forests in response to climate change through their study. (Joseph et al., 2009 and references cited therein).

\section{Economic impact of forest fires}

"Forestry is the second-largest land use after agriculture and accounts for about $1.5 \%$ of the nation's GDP” (World Bank, 2005). With 65 million people identified as tribal groups, they rely on the collection of non-wood forest products from forest areas for their livelihoods and are directly affected by forest fire. (Ashutosh \& Satendra, 2014). The economic losses associated with forest fires can be much greater for smallholders than for large holders, because they rely on the forest for a wide range of services and uses (Daniel Nepstad Adriana Moreira \& 1999a). The existing estimates of the potential cost of forest fires in India are likely underestimated at approximately INR 1,101 crore (US\$ 164 million, 2016 prices) per year (Bahuguna, 1999; World Bank, 2018). The loss of biodiversity, timber, increased carbon sequestration, soil moisture, and nutrient loss, etc., are not taken into account in this estimate. Furthermore, there is a lack of comprehensive data in India that can indicate forest losses in terms of area burned, values, and volume and regeneration destroyed by fire. The available forest fire estimates are not correct because the measured fire numbers and the area burned are underestimated. The rationale behind this is due to the absence of accountability (Bahuguna, V.K. \& Singh, 2001).Monetary damage from forest fires is usually only measured in terms of timber value for the loss of standing (natural or planted) trees, which is usually negligible in the case of low-intensity surface fires.(World Bank, 2018). Estimates may be enhanced by considering the direct and indirect effects on other industries like, for example, transport, utilities, loss of environmental services, etc. Thus, the estimate of INR 1101 crore/year is underestimated and the actual economic impact of forest fires is likely to be much higher.

\section{Fire management practices in India}

\section{Detection practices}

Globally, various wireless sensors, satellite systems, and neural network-based techniques are being employed in order to detect or manage forest fires. However, in India, currently, fires are detected using satellites and ground-based measurements. 


\section{Using Satellites and Remote Sensing}

In India, active forest fire detection systems rely on the MODIS (Moderate Resolution Imaging Spectroradiometer) instrument and the Visible Infrared Imaging Radiometer Suite (VIIRS) for satellite-based hotspot observation (World Bank, 2018). Using satellite detection, the forest fire alert system was first introduced in India in 2007-2008. Madhya Pradesh (Central Cluster) pioneered its Fire Warning Messaging System to distribute warnings to field workers through SMS text alerts (FAMS). After undergoing a significant number of improvements since 2004, the Forest Fire Alert System has shown a 10-fold upgrade of its version to Forest Fire Alert System Versions 3.0 (Fast 3.0) in the year 2019. This system is based on collaborative arrangements between NASAISRO (National Aeronautics and Space Administration- Indian Space Research Organization) and ISRO- FSI (Indian Space Research Organization-Forest Survey of India) (Forest Survey of India, 2011a).

\section{Ground-based detection of fires by field staff}

Even with advancements in remote sensing technology and warning systems, ground monitoring of forest fires will continue to be important. However, this mechanism is under-resourced in India. The forest service employs seasonal fire watchers from the local community to help with fire detection and response. These locally employed watchers are facing payment delays or shortages. No proper training instructions or equipment is provided to these fire watchers (World Bank, 2018). Thus, its important on the Indian government's part to strengthen the ground-based fire detection system.

Some of the commonly used fire detection techniques employed in India have been compared in terms of their cost and practicality in Table 4 .

Table 4: Comparison Amongst Different Forest Fire Detection Techniques

\begin{tabular}{|c|c|c|c|}
\hline $\begin{array}{c}\text { Name of the Fire } \\
\text { Detection Technique }\end{array}$ & Cost & Practicality & References \\
\hline $\begin{array}{l}\text { Wireless Sensor } \\
\text { Based Techniques }\end{array}$ & Medium & High & $\begin{array}{l}\text { (Aslan et al., 2012), (Díaz-Ramírez et al., } \\
\text { 2012), } \\
\text { (Bayo et al., 2010), (Bouabdellaha et al., } \\
\text { 2013) }\end{array}$ \\
\hline $\begin{array}{l}\text { Satellite Based } \\
\text { Systems }\end{array}$ & Very High & Very High & $\begin{array}{c}\text { (Oliva \& Schroeder, 2015), (Filizzola et al., } \\
\text { 2016), (Coppo, 2015), (Koltunov et al., } \\
\text { 2016) }\end{array}$ \\
\hline $\begin{array}{l}\text { Digital Camera } \\
\text { Sensor }\end{array}$ & High & Medium & $\begin{array}{c}\text { (Narasimha Rao et al., 2018), (Wong \& } \\
\text { Fong, 2014), (Çetin et al., 2013), (Q. X. } \\
\text { Zhang et al., 2018) }\end{array}$ \\
\hline Air Borne Techniques & High & High & $\begin{array}{c}\text { (Krüll et al., 2012), (Cruz et al., 2016), } \\
\text { (Allison et al., 2016),(Dennison \& Roberts, } \\
\text { 2009) }\end{array}$ \\
\hline $\begin{array}{l}\text { Neural Network } \\
\text { Based }\end{array}$ & Low & Low & $\begin{array}{l}\text { (Soliman et al., 2010), (Chauhan et al., } \\
\text { 2013) } \\
\text { (Giriraj et al., 2008), ( Zhang et al., 2009) }\end{array}$ \\
\hline
\end{tabular}

\section{Prevention Strategies}

Formulation of National Forest Policy in 1988, The National Master Plan for Forest Fire Control, and Guidelines in 2018 are some of the key initiatives that the Government of India has taken to manage the fire. Common methods for prevention of fire used in India include - fire line clearance and controlled burning to limit fuel loads, silvicultural practices such as selective thinning and fireadapted tree species planting in fire-prone areas, early warning, and fire hazard rating systems. The implementation of Joint Forest Management (JFM) village level committees was another significant step in the micro-level management of forest fires in India. 
The knowledge in systematic forest fire control is limited to the short term. There are weaknesses in the evaluation, ranging from fire detection to the coordination of preventive steps. At this time, the need to establish an adaptive management plan is critical. Sector-wise, with short- and long-term visions, clear points are suggested for the implementation of a holistic fire prevention plan in the light of climate change. Some of them include mitigation measures to minimize the uncertainty in baseline data, strengthen present fire-fighting programs, developing precautionary measures, integrating institutional efforts, publicity, extension, and training, legal measures, and funding of more programs aimed to improve the current status.

\section{Conclusion}

India with $21.67 \%\left(7,12,249 \mathrm{~km}^{2}\right.$,) area under forests is no exception to wildfires. $55 \%$ of forests in India are vulnerable to intermittent fires and wildfires affect around 3.73 million ha of forests per year in India. Wildfires in India impact the nation on different fronts, creating three major kinds of problems.

Environmental: The four geographic clusters in North-east, North-West Himalayan Region, Central, and Southern India best describe the fire ecology variation within India. Northeast accounts for the greatest no. of fire detections (nearly 55\%) while the Central region accounts for the largest area affected by forest fire (nearly 56\%). In the Western Himalayas, the impact of forest fire causes the loss of flora and fauna during the summer and is greater in these forests than any other anthropogenic factor. In the case of the North East cluster, in addition to other stresses, such as intensive grazing and browsing, frequent fires in short succession reduces species diversity and damages natural regeneration. Lastly, shorter duration fires occurred in the Central and Southern regions of the country have a detrimental impact on the composition and structure of forest, and diversity of species.

Social: In addition to reducing their ability to supply goods and services, forests face multiple aggravations that can cause adverse effects on their health and productivity. Being one of them, forest fires are ubiquitous and can take place in almost every eco-environment. Although fire has been used since ancient times in crop rotation, agricultural plowing, and pasture production for domesticated animals, socio-economic changes have caused traditional uses to be abandoned. Economic: For small holders, the economic losses associated with forest fires may be much greater than for large holders, since a wide variety of resources and uses depend on the forest. At an annual rate of approximately INR 1,101 crore, the current estimates of the economic costs of forest fires in India are almost certainly underestimated (US\$164 million, 2016 prices). However, not much data has been reviewed regarding the economic losses during the present forest fire phenomenon due to a lack of accountability. Many aims would be fulfilled by a more detailed accounting of the economic costs and benefits of forest fires in India.

Finally, with varying strategies and techniques adopted for forest fire detection and prevention, the appreciable difference has been discerned in the forest fire trends of the country.

\section{Nomenclature}

WHO: World Health Organization

FAO: Food and Agriculture Organization

MODIS: Moderate Resolution Imaging Spectroradiometer 
Mha: Million hectares

FSI: Forest Survey of India

\section{Acknowledgments}

This research did not receive any specific grant from funding agencies in the public, commercial, or not-for-profit sectors.

\section{References:}

Allison, R. S., Johnston, J. M., Craig, G., \& Jennings, S. (2016). Airborne optical and thermal remote sensing for wildfire detection and monitoring. Sensors (Switzerland), 16(8). https://doi.org/10.3390/s16081310

Archibald, S., Lehmann, C. E. R., Gómez-Dans, J. L., \& Bradstock, R. A. (2013). Defining pyromes and global syndromes of fire regimes. Proceedings of the National Academy of Sciences of the United States of America, 110(16), 6442-6447. https://doi.org/10.1073/pnas.1211466110

Ashutosh, D. K., \& Satendra. (2014). FOREST FIRE DISASTER MANAGAMENT National Institute of Disaster Management.

Aslan, Y. E., Korpeoglu, I., \& Ulusoy, özgür. (2012). A framework for use of wireless sensor networks in forest fire detection and monitoring. Computers, Environment and Urban Systems, 36(6), 614-625. https://doi.org/10.1016/j.compenvurbsys.2012.03.002

Bahuguna, V. K. (1999). Forest fire prevention and control strategies in India. International Forest Fire News, 20(20), 5-9.

Bahuguna, V. K., \& Upadhay, A. (2002). Forest fires in India: policy initiatives for community participation. International Forestry Review, 4(2), 122-127. https://doi.org/10.1505/ifor.4.2.122.17446

Bahuguna, V.K. \& Singh, S. . 2001. (2001). The forest fire situation in India. Int. Forest Fire News 26.

Bayo, A., Antolín, D., Medrano, N., Calvo, B., \& Celma, S. (2010). Early detection and monitoring of forest fire with a wireless sensor network system. Procedia Engineering, 5, 248-251. https://doi.org/10.1016/j.proeng.2010.09.094

Bonell, M., Purandara, B. K., Venkatesh, B., Krishnaswamy, J., Acharya, H. A. K., Singh, U. V., Jayakumar, R., \& Chappell, N. (2010). The impact of forest use and reforestation on soil hydraulic conductivity in the Western Ghats of India: Implications for surface and sub-surface hydrology. Journal of Hydrology, 391(1-2), 47-62. https://doi.org/10.1016/j.jhydrol.2010.07.004

Bouabdellaha, K., Noureddine, H., \& Larbi, S. (2013). Using wireless sensor networks for reliable forest fires detection. Procedia Computer Science, 19(Seit), 794-801. https://doi.org/10.1016/j.procs.2013.06.104

Certini, G. (2005). Effects of fire on properties of forest soils: A review. Oecologia, 143(1), 1-10. https://doi.org/10.1007/s00442-004-1788-8

Cetin, A. E., Dimitropoulos, K., Gouverneur, B., Grammalidis, N., Günay, O., Habiboğlu, Y. H., Töreyin, B. U., \& Verstockt, S. (2013). Video fire detection - Review. Digital Signal Processing: A Review Journal, 23(6), 1827-1843. https://doi.org/10.1016/j.dsp.2013.07.003

Chandra, K. K., \& Kumar Bhardwaj, A. (2015). Incidence of Forest Fire in India and Its Effect on Terrestrial Ecosystem Dynamics, Nutrient and Microbial Status of Soil. International Journal of Agriculture and Forestry, 5(2), 69-78. https://doi.org/10.5923/j.ijaf.20150502.01

Chauhan, A., Semwal, S., \& Chawhan, R. (2013). Artificial neural network-based forest fire detection system using wireless sensor network. 2013 Annual IEEE India Conference, INDICON 2013. https://doi.org/10.1109/INDCON.2013.6725913

Cochrane, M. A. (2003). Fire science for rainforests. Nature, 421(6926), 913-919. https://doi.org/10.1038/nature01437

Cochrane, M. A., Kodandapani, N., Cochrane, M. A., \& Sukumar, R. (2009). Forest fire regimes and their ecological effects in seasonally dry tropical ecosystems in the Western Ghats, India. Tropical Fire Ecology, 335-354. https://doi.org/10.1007/978-3-540-77381-8_12

Coppo, P. (2015). Simulation of fire detection by infrared imagers from geostationary satellites. Remote Sensing of Environment, 162, 84-98. https://doi.org/10.1016/j.rse.2015.02.016

Creswell I, M. H. (2018). Cresswell ID, Murphy H (2016). Biodiversity: Biodiversity. In: Australia state of the environment 2016, Australian Government Department of the Environment and Energy, Canberra, https://soe.environment.gov.au/theme/biodiversity, DOI 10.4226/94/58b65ac8288.

Cruz, H., Eckert, M., Meneses, J., \& Martínez, J. F. (2016). Efficient forest fire detection index for application in Unmanned Aerial Systems (UASs). Sensors (Switzerland), 16(6). https://doi.org/10.3390/s16060893

Daniel Nepstad Adriana Moreira, A. A., \& 1999a. (n.d.). Flames in the Rain Forest - Origins , Impacts and Alternatives to Amazonian Fires. 22, 1998-1999.

Debano, L. F. (1991). The effect of fire on soil properties. General Technical Report - US Department of Agriculture, Forest Service, INT-280, 151-156.

DeBano, L. F. (2003). The role of fire and soil heating on water repellency. Soil Water Repellency: Occurrence, Consequences, and Amelioration, 232, 193-202. https://doi.org/10.1016/B978-0- 444-51269-7.50020-5

Dennison, P. E., \& Roberts, D. A. (2009). Daytime fire detection using airborne hyperspectral data. Remote Sensing of Environment, 113(8), 1646-1657. 
https://doi.org/10.1016/j.rse.2009.03.010

Díaz-Ramírez, A., Tafoya, L. A., Atempa, J. A., \& Mejía-Alvarez, P. (2012). Wireless Sensor Networks and Fusion Information Methods for Forest Fire Detection. Procedia Technology, 3(4322), 69-79. https://doi.org/10.1016/j.protcy.2012.03.008

FAO, 2020. (2020). Global Forest Resources Assessment 2020 (Vol. 8). https://doi.org/10.1097/01.gim.0000223467.60151.02

Filizzola, C., Corrado, R., Marchese, F., Mazzeo, G., Paciello, R., Pergola, N., \& Tramutoli, V. (2016). RSTFIRES, an exportable algorithm for early-fire detection and monitoring: description, implementation, and field validation in the case of the MSG-SEVIRI sensor. Remote Sensing of Environment, 186, 196-216. https://doi.org/10.1016/j.rse.2016.08.008

Finlay, S. E., Moffat, A., Gazzard, R., Baker, D., \& Murray, V. (2012). Health impacts of wildfires. PLoS Currents, NOVEMBER 2012, 1-23. https://doi.org/10.1371/4f959951cce2c Flinn, M. A., \&

Pringle, J. K. (1983). Heat tolerance of rhizomes of several understory species. Canadian Journal of Botany, 61(2), 452-457. https://doi.org/10.1139/b83-052

Forest Survey of India. (2011a). India State of Forest Report 2011. India State of Forest Report 2011, 236-240. https://doi.org/http://www.fsi.org.in/cover_2011/uttarakhand.pdf

Forest Survey of India. (2011b). India State of Forest Report 2011. In India State of Forest Report 2011: Vol. II. https://doi.org/http://www.fsi.org.in/cover_2011/uttarakhand.pdf

Fowler, C. (2003). Human Health Impacts of Forest Fires in the Southern United States: A Literature Review. Journal of Ecological Anthropology, 7(1), 39-63. https://doi.org/10.5038/2162- 4593.7.1.3

Giriraj, A., Irfan-Ullah, M., Murthy, M. S. R., \& Beierkuhnlein, C. (2008). Modelling spatial and temporal forest cover change patterns (1973-2020): A case study from South Western Ghats (India). Sensors, 8(10), 61326153. https://doi.org/10.3390/s8106132

González-Cabán, A. (2013). The economic dimension of wildland fires. Vegetation Fires and Global Change Challenges for Concerted International Action. A White Paper Directed to the United Nations and International Organizations, January 2013, 229-237. http://treesearch.fs.fed.us/pubs/44383

Granström, A. (2001). Fire management for biodiversity in the European boreal forest. Scandinavian Journal of Forest Research, 16(1), 62-69. https://doi.org/10.1080/028275801300090627

Green, K., \& Sanecki, G. (2006). Immediate and short-term responses of bird and mammal assemblages to a subalpine wildfire in the Snowy Mountains, Australia. Austral Ecology, 31(6), 673-681. https://doi.org/10.1111/j.1442-9993.2006.01629.x

Grutzen, P. J., \& Andreae, M. O. (1990). Biomass burning in the tropics: Impact on atmospheric chemistry and biogeochemical cycles. Science, 250(4988), 1669-1678. https://doi.org/10.1126/science.250.4988.1669

Hemp, A. (2009). Climate change and its impact on the forests of Kilimanjaro. African Journal of Ecology, 47(SUPPL. 1), 3-10. https://doi.org/10.1111/j.1365-2028.2008.01043.x

Hussain, A., Negi, A. K., \& Todaria, N. P. (2018). History of Forest Fire around Globe, India and Uttarakhand-A Brief Scenario. Journal of Agriculture and Technology, 5(1), 7-14.

Jain, T. B., Gould, W. A., Graham, R. T., Pilliod, D. S., Lentile, L. B., \& González, G. (2008). A soil burn severity index for understanding soil-fire relations in tropical forests. Ambio, 37(7-8), 563-568. https://doi.org/10.1579/0044-7447-37.7.563

Jhariya, M. K., \& Raj, A. (2014). Effects of wildfires on flora, fauna and physico-chemical properties of soilAn overview. Journal of Applied and Natural Science, 6(2), 887-897. https://doi.org/10.31018/jans.v6i2.550

Jhariya, M.K. S.S. Bargali, S.L. Swamy, B. Kittur, Kiran Bargali, and G. V. P. 2014. (2014). "Impact of Forest Fire on Biomass and Carbon Storage Pattern of Tropical Deciduous Forests in Bhoramdeo Wildlife Sanctuary, Chhattisgarh. June 2018.

Joseph, S., Anitha, K., \& Murthy, M. S. R. (2009). Forest fire in India: A review of the knowledge base. Journal of Forest Research, 14(3), 127-134. https://doi.org/10.1007/s10310-009-0116-x

Khaki, B.A., Singh. V.R.R., Wani A.A. \& thakur, R. K. (2015). Effects of forest fire on soil nutrients in blur pine (pinus wallichiana A.B. Jackson) ecosystems. Indian Forester, 141(4), 355-360.

Kim, M., Harris, T., \& Alevy, J. (2011). Measuring Regional Economic Impacts from Wildfire: Case Study of Southeast Oregon Cattle-Ranching Business. January.

Kittur, B. H., Swamy, S. L., Bargali, S. S., \& Jhariya, M. K. (2014). Wildland fires and moist deciduous forests of Chhattisgarh, India: divergent component assessment. Journal of Forestry Research, 25(4), 857-866. https://doi.org/10.1007/s11676-014-0471-0

Kodandapani, N., Cochrane, M. a., \& Sukumar, R. (2004). Conservation Threat of Increasing Fire Frequencies in the Western Ghats, India. Conservation Biology, 18(6), 1553-1561. https://doi.org/10.1111/j.15231739.2004.00433.x

Kodandapani, N., Cochrane, M. A., \& Sukumar, R. (2008). A comparative analysis of spatial, temporal, and ecological characteristics of forest fires in seasonally dry tropical ecosystems in the Western Ghats, India. Forest Ecology and Management, 256(4), 607-617. https://doi.org/10.1016/j.foreco.2008.05.006

Koltunov, A., Ustin, S. L., Quayle, B., Schwind, B., Ambrosia, V. G., \& Li, W. (2016). The development and first validation of the GOES Early Fire Detection (GOES-EFD) algorithm. Remote Sensing of Environment, 184, 436-453. https://doi.org/10.1016/j.rse.2016.07.021

Krishnaswamy, J., Bawa, K. S., Ganeshaiah, K. N., \& Kiran, M. C. (2009). Quantifying and mapping biodiversity and ecosystem services: Utility of a multi-season NDVI based Mahalanobis distance surrogate. Remote Sensing of Environment, 113(4), 857-867. https://doi.org/10.1016/j.rse.2008.12.011

Krüll, W., Tobera, R., Willms, I., Essen, H., \& Von Wahl, N. (2012). Early forest fire detection and verification using optical smoke, gas and microwave sensors. Procedia Engineering, 45, 584- 594. https://doi.org/10.1016/j.proeng.2012.08.208 
Letnic, M., \& Dickman, C. R. (2005). The responses of small mammals to patches regenerating after fire and rainfall in the Simpson Desert, central Australia. Austral Ecology, 30(1), 24-39. https://doi.org/10.1111/j.1442-9993.2004.01410.x

McKenzie, D., Gedalof, Z., Peterson, D. L., \& Mote, P. (2004). Climatic change, wildfire, and conservation. Conservation Biology, 18(4), 890-902. https://doi.org/10.1111/j.1523- 1739.2004.00492.x

Murthy, K. K., Sinha, S. K., Kaul, R., \& Vaidyanathan, S. (2019). A fine-scale state-space model to understand drivers of forest fires in the Himalayan foothills. Forest Ecology and Management, 432(January), 902-911. https://doi.org/10.1016/j.foreco.2018.10.009

Narasimha Rao, G., Jagadeeswara Rao, P., Duvvuru, R., Bendalam, S., \& Gemechu, R. (2018). Fire detection in Kambalakonda Reserved Forest, Visakhapatnam, Andhra Pradesh, India: An Internet of Things Approach. Materials Today: Proceedings, 5(1), 1162-1168. https://doi.org/10.1016/j.matpr.2017.11.197

Narendran, K., Indu, M. K., S., S. H., S., D. H., H., R. N., \& R., S. (2001). Nontimber forest product extraction, utilization and valuation: a case study from the Nilgiri Biosphere reserve, Southern India. Economic Botany, 55(4), 528-538.

North, B. M. P., Stephens, S. L., Collins, B. M., Agee, J. K., Aplet, G., Franklin, J. F., \& Fulé, P. Z. (2015). Reform forest fire management. Science 349(6254):1280-1281. Science.

Oliva, P., \& Schroeder, W. (2015). Assessment of VIIRS 375m active fire detection product for direct burned area mapping. Remote Sensing of Environment, 160, 144-155. https://doi.org/10.1016/j.rse.2015.01.010

Parashar, B. S. (2003). The Impact Of Forest Fire On Forest Biodiversity In The Indian Himalayas (Uttaranchal). Proceeding of XII world Forestry Congress, Canada 0358-B1.

Paula, S., Arianoutsou, M., Kazanis, D., Tavsanoglu, Ç., Lloret, F., Buhk, C., Ojeda, F., Luna, B., Moreno, J. M. Rodrigo, A., Espelta, J. M., Palacio, S., Fernández-Santos, B., Fernandes, P. M., \& Pausas, J. G. (2009). Firerelated traits for plant species of the Mediterranean Basin. Ecology, 90(5), 1420. https://doi.org/10.1890/081309.1

Pelegrin, N., \& Bucher, E. H. (2010). Long-term effects of a wildfire on a lizard assemblage in the Arid Chaco forest. Journal of Arid Environments, 74(3), 368-372. https://doi.org/10.1016/j.jaridenv.2009.09.009

Penner, J. E., Dickinson, R. E., \& O’Neill, C. A. (1992). Effects of aerosol from biomass burning on the global radiation budget. Science, 256(5062), 1432-1434. https://doi.org/10.1126/science.256.5062.1432

Piñol, J., Terradas, J., \& Lloret, F. (1998). Climate warming, wildfire hazard, and wildfire occurrence in coastal eastern Spain. Climatic Change, 38(3), 345-357. https://doi.org/10.1023/A:1005316632105

Pitman, A. J., Narisma, G. T., \& McAneney, J. (2007). The impact of climate change on the risk of forest and grassland fires in Australia. Climatic Change, 84(3-4), 383-401. https://doi.org/10.1007/s10584-007-9243-6

Producer, S., Books, C., \& Nature, O. N. (2006). Hotspots revisited. Choice Reviews Online, 43(05), 43-2786-43-2786. https://doi.org/10.5860/choice.43-2786

Puri, K., Areendran, G., Raj, K., Mazumdar, S., \& Joshi, P. K. (2011). Forest fire risk assessment in parts of Northeast India using geospatial tools. Journal of Forestry Research, 22(4), 641-647. https://doi.org/10.1007/s11676-0110206-4

Ramakrishnan, P. S. (2007). Traditional forest knowledge and sustainable forestry: A north-east India perspective. Forest Ecology and Management, 249(1-2), 91-99. https://doi.org/10.1016/j.foreco.2007.04.001

Rodgers, W. A. (1986). The Role of Fire in the Management of Wildlife Habitats: A Review'. Indian Forester, 112: 845857. Indian Forester, 112(10).

Saha, S. (2002). Anthropogenic fire regime in a deciduous forest of central India. Current Science, 82(9), 1144-1147.

Singh, J. S., Rawat, Y. S., \& Chaturvedi, O. P. (1984). Replacement of oak forest with pine in the Himalaya affects the nitrogen cycle. Nature, 311(5981), 54-56. https://doi.org/10.1038/311054a0

Soliman, H., Sudan, K., \& Mishra, A. (2010). A smart forest-fire early detection sensory system: Another approach of utilizing wireless sensor and neural networks. Proceedings of IEEE Sensors, January 2017, 1900-1904. https://doi.org/10.1109/ICSENS.2010.5690033

Stephens, S. L. (2005). Forest fire causes and extent on United States Forest Service lands. International Journal of Wildland Fire, 14(3), 213-222. https://doi.org/10.1071/WF04006 Úbeda, X., \& Sarricolea,

P. (2016). Wildfires in Chile: A review. Global and Planetary Change, 146, 152-161. https://doi.org/10.1016/j.gloplacha.2016.10.004

Verma, S., \& Jayakumar, S. (2012). Impact of forest fire on physical, chemical and biological properties of soil: A. Proceedings of the International Academy of ..., 2(3), 168-176. http://www.iaees.org/publications/journals/piaees/articles/2012-2(3)/impact-of-forest-fire.pdf

Vidal-Macua, J. J., Ninyerola, M., Zabala, A., Domingo-Marimon, C., Gonzalez-Guerrero, O., \& Pons, X. (2018). Environmental and socioeconomic factors of abandonment of rainfed and irrigated crops in northeast Spain. Applied Geography, 90(September 2017), 155-174. https://doi.org/10.1016/j.apgeog.2017.12.005

Wilson, A. M., Latimer, A. M., Silander, J. A., Gelfand, A. E., \& de Klerk, H. (2010). A Hierarchical Bayesian model of wildfire in a Mediterranean biodiversity hotspot: Implications of weather variability and global circulation. Ecological Modelling, 221(1), 106-112. https://doi.org/10.1016/j.ecolmodel.2009.09.016

Wong, A. K. K., \& Fong, N. K. (2014). Experimental study of video fire detection and its applications. Procedia Engineering, 71, 316-327. https://doi.org/10.1016/j.proeng.2014.04.046

World Bank, 2018. (2018). Strengthening Forest Fire Management in India”. World Bank, Washington DC.

www.fsi.nic.in

World Bank. (2005). India Unlocking Opportunities for Forest-Dependent People in India. I(34481). Wotton, B. M., Martell, D. L., \& Logan, K. A. (2003). Occurrence in Ontario. Climatic Change,

275-295.

Wotton, B. M., Nock, C. A., \& Flannigan, M. D. (2010). Forest fire occurrence and climate change in Canada. International Journal of Wildland Fire, 19(3), 253-271. https://doi.org/10.1071/WF09002

WWF, I. (2011). Forests for a living planet. WWF Living Forests Report, 1-37.

http://www.wwf.se/source.php/1359561/Living Forests Report_Chapter 1_2011.pdf

Zhang, D., Han, S., Zhao, J., Zhang, Z., Qu, C., Ke, Y., \& Chen, X. (2009). Image based Forest fire detection using dynamic characteristics with artificial neural networks. IJCAI International Joint Conference on Artificial Intelligence, 2, 290-293. https://doi.org/10.1109/JCAI.2009.79

Zhang, Q. X., Lin, G. H., Zhang, Y. M., Xu, G., \& Wang, J. J. (2018). Wildland Forest Fire Smoke Detection Based on Faster R-CNN using Synthetic Smoke Images. Procedia Engineering, 211, 441-446.

https://doi.org/10.1016/j.proeng.2017.12.03 